2002) but does not mention that Audi has his own version of moderate foundationalism that is different from Plantinga's. After the publication of TSF, Audi has developed his model in the context of theological epistemology in his Reason and Religious Commitment (OUP, 2011). Audi's moderate foundationalism might be a serious option for those who are not too keen on the proper functionalism of Plantinga.

In conclusion, I admit that although I am not sure whether I identify myself directly with the analytic theology movement, I very much sympathize with the approach that it represents and find myself agreeing with most of what TSF says, especially with the critiques of various nonfoundationalist theologies and the accompanying robust theological realism. TSF splendidly identifies and analyzes the deep philosophical issues inherent in theological proposals. As for the attempt to ground theology in Plantinga-style proper functionalism, I am not that sure. Despite my worries about Rauser's own solution and his limited discussion of current internalist proposals, I wholeheartedly recommend the book to theologians that are interested in the epistemology of theology as well as to philosophers that are thinking about theology and theological method. That being said, I would not direct theological and philosophical novices to the book, because of the density of its arguments and the need for extensive background knowledge for understanding it.

\title{
SCOTT DAVISON
}

\section{Morehead State University}

\section{Vincent Brümmer, What Are We Doing When We Pray?: On Prayer and the Nature of Faith, Ashgate, 2008.}

This is a revised and expanded version of a book originally published by the author in 1984. Part I, which concerns prayer in the Christian tradition, takes up the first seven chapters of the book, and Part II, which concerns the nature of Christian faith, takes up the final three chapters. Here I shall summarize briefly the contents of each chapter before making some general remarks about the audience to whom this book is most likely to be useful.

Chapter 1 outlines the questions to be discussed in the book, including some methodological ones about how to study the phenomenon of 
prayer and how to think about its efficacy. Included in this discussion is a helpful explanation of the difference between a particular prayer, such as Elijah's prayer in 1 Kings 18, and a scientific experiment, such as the measurement of the deflection of starlight by the sun's gravitational field that confirmed Einstein's theory of relativity. Brümmer also discusses the difficulties involved in attempts to test the efficacy of petitionary prayer by appeal to statistical analysis, with reference to the particular example of Francis Galton (whose work was first published in 1872). He argues convincingly that since petitionary prayer involves personal interaction with a free agent, as opposed to some kind of natural force, it cannot be studied reliably using the usual methods of scientific testing.

Chapter 2 begins with a discussion of the views of Kant and T. R. Miles, both of whom argue (but for different reasons) that the proper function of prayer is to change the one praying, not to have any effect on God. Brümmer admits that changing the person who prays is important, and cites a number of authoritative sources from the tradition to make his point, but also argues that Kant and Miles are wrong to suggest that prayer functions completely independently of belief in the real existence of God.

Chapter 3 includes an extended discussion of the presuppositions implicit in the claim that petitionary prayer is impetratory, that is, successful in moving God to act. First, there is the presupposition of two-way contingency: the thing requested must be neither impossible nor necessary for God to provide. Second, the request involved in the offering of the petitionary prayer is necessary but not sufficient for God's action. In addition, this chapter contains an extended treatment of the worry that since God is immutable, petitionary prayer is pointless. Brümmer argues that St. Thomas Aquinas' picture of the immutability of God, together with Thomas' belief that God is timelessly eternal, implies that all events would be predetermined from eternity, so that petitionary prayer would be pointless. The argument here is brief and sketchy, though; Aquinas scholars will not find it compelling. After considering (but not endorsing) an alternative formulation of immutability from Peter Geach (involving a distinction between real and so-called 'Cambridge' change), Brummer quotes John Lucas with approval, who says (roughly) that God can change in some respects but not others. The conclusion is that if God is absolutely immutable, then petitionary prayer is pointless, but we should not think that God is absolutely immutable. 
Chapter 3 also includes a discussion of the worry that since God is omniscient, petitionary prayer is pointless. Brümmer criticizes Boethius' defence of the claim that God is timelessly eternal, concluding that 'Petitionary prayer presupposes a God who can have a temporal relation with human persons and the world' (p. 47). Again, the argument is rather quick; defenders of timeless eternity will not find it compelling. Based on the contingency presupposition mentioned above, Brümmer argues that the future does not exist yet, and hence cannot be known by anyone in advance, including God. So he accepts the open theist's picture of the limits of divine omniscience. As many readers know, a convoluted, highly technical debate between open theists, defenders of timeless eternity, and defenders of middle knowledge has exploded in the past twenty years or so. Those who follow that debate closely will not find Brümmer's discussion of this question very satisfying because the arguments, once again, are brief and sketchy.

In chapter 4, Brümmer discusses impetratory prayer and the goodness of God. Stressing that petitionary prayer changes both God and the petitioner, he argues that praying for other people signals a willingness to help them where possible, and thus that corporate intercessory prayer involves multiple people participating in bringing about the kingdom of God. He also analyzes the prayer, 'Thy kingdom come', as involving a submission to God on behalf of the person praying and a request for God to assume authority over us and grant us 'the gifts that enable us to attain the "union of wills" with him' (p. 62). Here he also raises a difficult question about intercessory prayer, one that has received some attention in the literature: if intercessory prayer for others is regarded as effective, does this mean that God would have withheld assistance had prayers not been offered? Considering and rejecting solutions offered by others, Brümmer stresses that God's action in the world is (typically) mediate, involving secondary causes, but it is not clear how this addresses the problem at hand.

Chapter 5 concerns the nature of divine agency. Brümmer argues persuasively that God's answering of prayers need not involve miraculous intervention into the natural order, but then raises the following interesting question: if a given event has a natural explanation, then how can it be an answer to prayer as well? He responds by claiming that not only would a deterministic approach to nature preclude human freedom, it is also outdated - according to current science, there is always 'room' for things to be otherwise, even in connection with highly 
probable events, because of quantum indeterminacy in nature. In this way, Brümmer signals his allegiance to a libertarian account of human freedom. Drawing heavily on the work of J. R. Lucas, he argues that a free human action can be viewed as something for which both its human author and God are responsible at the same time, calling this a 'double agency' theory. Does such an account make it impossible to tell whether or not God has answered one's prayer, when the thing requested comes to be, since God's role in the natural world is, as a rule, invisible? Brümmer thinks not, arguing that 'The ability to recognize God's actions by looking at the world through the eyes of faith requires training, in which petitionary prayer has an important function' (p. 87). There are deep and difficult issues at stake here, both metaphysical and epistemological, and no doubt some readers will find Brümmer's treatment of them to be rather brief and general.

Chapter 6 elaborates the distinction between unitive and personal mysticism, and defends the importance of prayers of petition, penitence, and thanksgiving for a personal relationship with God. Along the way, Brümmer provides detailed and interesting accounts of the nature of prayers of penitence and the conditions in which gratitude (and the attribution of responsibility in general) is appropriate. At one point, Brümmer commits himself to the conclusion that 'I can only praise or blame you (or be grateful or resentful) for what I perceive you to have done, if I know what your intention was in doing what you did' (p. 112). This requirement is probably too strong, though (which is probably good, because often we do not have epistemic access to the intentions of others, human or divine, and yet gratitude and resentment can still be appropriate in some of those cases).

Chapter 7 contains a detailed discussion of the relationship between morality, religion, general principles, and the use of models and metaphors. Brümmer argues that the relation between prayer and the moral life is an internal one, not an external or accidental one, and that 'Prayer and the life of fellowship with God are impossible without each other' (p. 131).

Chapter 8 begins Part II of the book, and argues that as a result of the Enlightenment, we have come to view religious belief as a kind of theory that admits of confirmation or disconfirmation in roughly the same way that scientific theories do. Brümmer argues to the contrary that faith is not a matter of propositional belief alone, and that it is 'not only a way of seeing but also a way of living or a form of life' (p. 145). Chapter 9 
continues this theme by developing in some detail the idea of the 'eyes of faith'. He argues that 'Religious experience should not be viewed as an extraordinary kind of extra-sensory perception, but rather as ordinary experience (including ordinary sense perception) looked upon with the eyes of faith' (p. 149). He applies this framework to the problem of confronting evil in the world, which requires seeing the world through the eyes of faith, and discusses the role of metaphor in such seeing.

Chapter 10 contains a discussion of truth, verification, and the life of faith and prayer. Here Brümmer argues that the life of faith presupposes objectively true beliefs about the nature and existence of God, beliefs that are implicit in the forms of prayer discussed earlier in the book. He also argues that belief in the existence of God is justified for believers by showing that it is a necessary presupposition constitutive for the way in which they make sense of their lives and experience' (p. 177), not by appeal to the sorts of neutral perceptual evidence that enable us to determine which scientific theory is most justified. But he does not take this to imply that there is no neutral territory on which believers and non-believers can meet - instead, he says that

The debate between religious believers and secular atheists should therefore deal primarily with the coherence, intelligibility, relevance and adequacy of the theistic form of life and understanding as such and only in a secondary or derived sense with the truth of its constitutive presupposition about the existence of God. In this debate secular atheists should also be called upon to account for their alternative view of life. (pp. 181-2)

As before, here Brümmer engages deep and important epistemological questions without hesitation, and sketches an important position worthy of consideration.

The main virtue of Brümmer's book is the wide range of topics that it covers in order to present a coherent, complete picture of the role of prayer in the life of Christian faith. It is important to state clearly that his project is thoroughly Christian from the beginning; often he refers to scriptural passages or influential thinkers from the tradition as evidence for or against various positions. So Brümmer's book would be very useful for those who teach at Christian universities where there is a reasonable expectation that the students would have more than a passing acquaintance with the tradition and perhaps some interest in pursuing a life of Christian faith. 
For those who are interested in contemporary philosophy of religion, especially in the analytic tradition, Brümmer's book provides a helpful introduction to many questions concerning the nature of prayer, and shows how all of these questions are related to one another. But as indicated, those who are interested in technical debates among professional philosophers will find the book disappointing because the arguments are often brief and sketchy. Some of the sources cited are also a bit outdated, in the sense that positions outlined therein have been superseded by much more detailed and complete accounts generated by the many philosophers working in the philosophy of religion since the first edition of Brümmer's book was published in 1984.

In conclusion, What Are We Doing When We Pray? is a substantial and important contribution to contemporary philosophy of religion, a contribution that will be especially interesting to those who wish to explore and elucidate a distinctively Christian conception of the life of prayer.

\section{JOSHUA C. THUROW \\ University of Texas - San Antonio}

\section{Jesse Bering, The God Instinct: The Psychology of Souls, Destiny, and the Meaning of Life, Nicholas Brealey Publishing, 2011.}

In the last 20 years cognitive science has gone where others have recently feared to tread: developing and testing explanations of religious beliefs and behaviours. Not only has their work flourished, but it has also captured the imagination of a segment of the reading public. Several surveys of the field for the general reading public have already been published from Pascal Boyer's Religion Explained (2001) to Justin Barrett's Why Would Anyone Believe in God? (2004), Todd Tremlin's Minds and Gods (2006), and Daniel Dennett's Breaking the Spell (2006) (not to mention more scholarly works such as Scott Atran's In Gods We Trust (2002) and Jeffrey Schloss and Michael Murray's (ed.'s) The Believing Primate (2009), as well as Robert Hinde's Why Gods Persist (1999/2010) and David Sloan Wilson's Darwin's Cathedral (2002)). Jesse Bering, a leading researcher in the cognitive science of religion and one of the principle investigators on the Explaining Religion Project, has penned his own entry in this 